\title{
Siyāda and Imamate in Eighteenth-Century India
}

\author{
The Ṭarīqa Muhạmmadiyya Khālișa and the Sunnī-Shīi Sectarian Conflict
}

\author{
Soraya Khodamoradi
}

During the eighteenth and early nineteenth centuries, when the central authority of the Indian Mughal Empire was gradually replaced by multiple centres of power and culture, the long-standing debates between the different denominations such as the Sunnīs and the Shīis over their contested Islamic traditions thrived again. Shīi rulers of the newly emerging centres patronised their religious scholars ( ulamà) and seminaries and helped disseminating Shī̄ practices and rituals. In response to this development, Sunnīs began to reconsider their relationship with Shīism and produced a considerable number of polemical texts. Sunnī religious revivalists in South Asia even made the discussions about Shīism part of their reform agendas. Outstanding reformers such as Shāh Walī Allāh (d. 1762), Maẓhar Jān-i Jānān (d. 178o), Muḥammad Nāṣir 'Andalīb (d. 1758), Khwāja Mīr Dard (d. 1785), and Shāh 'Abd al-'Azīz (d. 1824) engaged with the issue in different ways and for various aims, which ranged from uniting the main Islamic denominations to rebutting the Shī̄i position altogether.

Among these revivalists, the Sufi reformer Mīr Dard, the theoretician of the Tarīqa Muhammadiyya Khäliṣa ("Pure Muhammadan Path") founded by his father, 'Andalīb, paid specific attention to denominational polemics. He propounded the notion of taríqa wäthiqa ("trustworthy path") as a framework for the reconstruction and reinvigoration of the doctrines of siyāda ("blood affiliation with the Prophet") and of the imamate. This was presented by him as a solution for the sectarian and theological conflicts between the Shī'is and the Sunnīs. It was also supposed to support his and his father's authority as descendants of the Prophet and as inheritors of the knowledge transmitted by his cousin and son-in-law 'Alī b. Abī Ṭālib.

This attempt came at a time when the decline of the imperial power created a dispute over moral and religious authority among different Islamic groups. Focusing on Dard's texts and employing both conceptual-semantic and contextual-historical methods of analysis, this chapter explores the role of siyāda and imāma (leadership) in Dard's philosophy of Taríqa Muhammadiyya. It searches for the reason behind his insistence to be recognised as a member 
of the Prophetic family and his preference for the titles sayyid and imam instead of other honorifics such as walī, shaykh, Sufi, or 'ālim. Moreover, it deals with Dard's prioritising of the principles of siya $\bar{d} a$ and imamate over companionship (șhạba) and caliphate (khiläfa), since this seems counter-intuitive to his own Sunnī background and Mujaddidī affiliation. Contextualising Dard's discussions of siyāda and imamate within the framework of his taríqa wāthiqa, it brings out why his position must be regarded as a considerable change in the Sunni discourse for the sake of a reconciliation with the Shīa in early modern India.

\subsection{Shīī Social and Political Dynamics}

With its doctrinal focus on the household of the Prophet and his offspring, and its belief in their infallibility and merit and their right to both worldly leadership and spiritual guidance of the Muslim community (umma), the Shía gained considerable influence in India during the eighteenth century. In the early 170os, the emperor Bahādur Shāh's (r. 1707-12) decision to introduce Shīi i practices into his court at Delhi signalled a turn of fortunes for the Shīī community. ${ }^{1}$ As the central authority of the Mughal Empire weakened, Shīì notables founded and ruled significant successor states and new centres of power. Bengal was almost independently ruled by Shīi governors (known as nawwābs), who were appointed by the Mughals from 1701 until the British takeover of 1757. The state of Awadh, whose rulers themselves belonged to a sayyid (pl. sādāt) family originating from Nishapur, the ancient capital of Khorasan in Iran, made the greatest impact on the development of Shīism in the subcontinent. ${ }^{2}$ Hyderabad, the largest princely state in south India, although hardly comparable in this respect with Bengal and Awadh, also had its fair share of Persian and Shīì sayyid nobles, courtiers, scribes, and poets who were active on the political and cultural scene and at the court alike.

In these new centres of Shīi power and culture, sectarian antagonism between the different Islamic currents gained a renewed momentum. This included opposition between Sunnī and Shīì communities but also between the traditionalist akhbāà and rationalist ușülì schools among the Shīīs

1 Nasr, The Shi'a Revival, 98.

2 Rieck, The Shias of Pakistan, 1-3. See also Cole, Roots of North Indian Shïism, 36-42. Before the eighteenth century, India witnessed Shī'i-led principalities such as the Bahmanids in Deccan (r. 1347-1526), the Adilshahis in Bijapur until 1686, the Nizamshahis of Ahmadnagar (r. 1490-1633), and Qutbshahis (r. 1512-1687) (Ālemī, "Mulūk-i bahmanī"). 
themselves. ${ }^{3}$ Shīi 1 rulers promoted their understanding of Islam to legitimise their authority and patronised both the culture and scholarship of the Shi'a learned classes. They encouraged 'ulam $\bar{a}$ ' to challenge their Sunnī counterparts, founded seminaries, and helped to disseminate rituals such as 'Āshürā' (commemorating the death of Ḥusayn b. 'Alī). ${ }^{4}$ Even under the Âsaf Jāhīs (r. 1724-1948), the Sunnī successors to the Quṭb Shāhīs (r. 1591-1687 in Hyderabad), ministers of the state gave public support to the great Shīi ì shrines and patronised Muharram religious festivals. ${ }^{5}$

The sādàt rulers of Awadh (1722-1856) were devout Shīiss who spent huge sums for the construction of mosques and imāmbārgās, the latter being congregation halls for the commemoration ceremonies especially during Muharram. They were also great patrons of an 'ulamä' class following the rationalist school of jurisprudence and insisting on holding Friday congregational prayers in Lucknow and Faizabad, which spread from there to other towns. Moreover, Iranian merchants in Awadh and their descendants in towns like Murshidabad designated endowments for the promotion of 'azādāri (mourning and lamentation). These measures also attracted many Shīì scholars and literati from both India and Iran to these regions. In 1775, Nawab Asaf al-Daula (d. 1797), who initiated the construction of a number of religious buildings like the Asafĩ Imāmbāra and the Jāmi` Masjid in Lucknow, invited a large number of Shī' ' 'ulama $\vec{a}^{3}$ to the Awadh court. ${ }^{6}$ Against this backdrop, the leading Shī' 'ulam $\bar{a}$ ' of Lucknow grew immensely wealthy as a result of official salaries and the collection and redistribution of khums (the religious obligation of paying one-fifth of the wealth acquired from certain sources) and zakāt (annual payment according to Islamic law on certain kinds of property). They reached the peak of their influence with the establishment of a Shī'i judiciary and a large Shīì seminary later under Amjad 'Alī Shāh (r. 1842-74). ${ }^{7}$

3 The correspondence between the Akhbārī scholar Mīr Yūsuf 'Alī Astarābādī (d. seven-

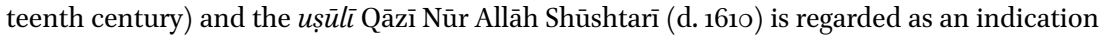
of the Akhbārī-ușūlī schism in the Indian context. For the correspondence, see Ja'fariyān, "Mukātibat", 2-15. For details on Akhbārī-ușūlì thought and historical development, see Newman, "The Nature of Akhbārī/Ușūlī Dispute, Part ı"; Newman, "The Nature of Akhbārī/ Ușūlī Dispute, Part 2"; Böwering, "Introduction”, 14; Mavani, Religious Authority, 12-13, 130; Gleave, Scripturalist Islam, 177-9o.

4 Rizvi, "Faith Deployed", 12-14; Nasr, The Shi'a Revival, 99.

5 Pinault, The Shicites, 78.

6 Rezavi, "The State, Shi'as and Shi'ism", 44.

7 Rieck, The Shias of Pakistan, 3. 
The domination of Shī' 'ulamä', landholders, and state officials in cities such as Awadh coincided with a decline of the fortunes of the Sunnī noble class and religious institutions. Sunnī religious leaders saw the Shī'ì ascendancy, among other factors, as a manifestation of Islam's decline, and hence their demand for Islamic revival and reform included the refutation of Shīism. ${ }^{8}$ Disputes and conflicts between Sunnī and Shī̄i factions at the court and in society at large became a recurrent feature of India's Muslim society during this period. ${ }^{9}$ Bahādur Shāh's demonstration of pro-Shīì tendencies, for instance, led to sectarian conflicts in Lahore. In 1711, his order to add the title wași ("heir, legatee, or the executor of the will of Muhammad") to the epithets for Imam 'Ali during mosque sermons ignited riots provoked by Sunni theologians..$^{10}$ These riots multiplied in Delhi and other north Indian towns throughout the eighteenth century and tensions further intensified following the invasions of Nādir Shāh Afshār (1739-40) and Aḥmad Shāh Durrānī (six times between 1748 and 1762). Similar tensions had already arisen in India since the sixteenth century. Before Bahādur Shāh, his father, Aurangzeb (r. 1658-1707), had held strict orthodox Sunnī views and fought against Shīī religious practices. Although he heavily relied on the services of Iranians and other Shīiss for military campaigns as well as official and administrative duties, during his reign, Muharram processions had been banned and the Shīi kingdoms in the Deccan subjugated. The compendium of Hanafĩ Islamic law prepared by Sunnī 'ulama $\bar{a}$ ' on his orders, the Fatāwā-yi 'älamgìriyya (Alamgir's fatwas), even proclaimed those Shī'is who cursed the first two caliphs as heretics. ${ }^{11}$

With the resurgence of Shì'ism, and with the rise of the Shīi sayyids of Bārha, who had become kingmakers during the first phase of Mughal decline, strong anti-Shīi i polemics emerged in northern India. ${ }^{12}$ The major controversial issues between Sunnīs and Shīiss, such as the true successorship of the Prophet, were actively debated among both communities with Sunnī religious leaders condemning Shīī practices such as Muharram processions as excessive. An outstanding example is Shāh Walī Allāh, the erudite Naqshbandī Sufi and scholar, who attempted to develop his own reformulation of Sufism in

\footnotetext{
8 Nasr, The Shi'a Revival, 99.

9 Rizvi, "Faith Deployed", 13.

10 Irvine, Later Mughals, 130-2.

11 Rieck, The Shias of Pakistan, 2-6.

12 The name of Bārha applied, from Akbar's reign onwards, to a community of sayyids in possession of a particular group of twelve villages in the Dōāb (Muẓaffarnagar district, UP) (see Rizvi, "Bārha Sayyids").
} 
the context of a broader reform agenda that involved Islamic jurisprudence, Qurānic exegesis, hadìth studies, and theology.13

Wali Allāh's preoccupation with the theory of the caliphate, one of the most striking eighteenth-century discussions that challenged the Shìi concept of the imamate under the Prophet's progeny, clearly reflects the level of anti-Shīa $a$ polemics among Naqshbandīs at that time. Walī Allāh divides the historical caliphates into three categories: (a) the "special" caliphate (khiläfa khāsșa), which included the rule of the rightly guided caliphs (632-61), with the addition of the eighth Umayyad caliph 'Umar b. 'Abd al-'Azīz (d. 720) as an ideal ruler; (b) the "general" caliphate ('āmma), in which Walī Allāh follows the classical theory of the Shāfiī reforming jurist Abū l-Ḥasan al-Māwardī (d. 1058) and regards Mu'āwiya, the first Umayyad caliph, as rightful; and (c) the "tyrannical" caliphate ( jābira), which cannot be accepted as rightful at all. Walī Allāh believed that the first form of caliphate collapsed because of fitna (strife, sedition), which led to the division of the Muslim community under the fourth caliph, 'Ali (d. 66o), and to the cessation of jihād after the murder of the third caliph, 'Uthmān (d. 656). According to him, the murder of 'Uthmān was the dividing line between the ideal age and the age of anarchy that followed. ${ }^{14} \mathrm{He}$ declares that Shīi Imams cannot be regarded as special caliphs because they did not perform hijra (the migration of the Prophet from Mecca to Medina) and were not among the first companions to accept Islam. Furthermore, they did not have actual power and authority over the Muslim community as the four caliphs did. ${ }^{15}$

Walī Allāh's attempts to reconcile the divergent positions among Muslims barely took the Shīî doctrine into account. He was steadfast in his defence of the Sunnī positions and his repudiation of Shīī views of caliphal succession. In a letter to the king and nobles of his time, he stresses that

strict orders should be issued in all Islamic towns forbidding religious ceremonies publicly practiced by infidels ... On the tenth of Muharram, the Shīis should not be allowed to go beyond the bounds of moderation, neither should they be rude nor repeat stupid things [i.e., reciting tabarrā $]^{16}$

\footnotetext{
13 Hermansen, trans., The Conclusive Argument, xxix; Voll, Islam, 58-61; For Shāh Walī Allāh's religious and reformist thought, see Baljon, Religion and Thought; Rizvi, Shah Wali-Allah; Dallal, "The Origins and Objectives".

14 Ahmad, "An Eighteenth-Century Theory of the Caliphate", 135-40.

15 The requirements of the special caliphate and the description of the fitna are elaborated in detail in Walī Allāh, Izālat al-khafä’, 85-234, 487-586.

16 Quoted in Rizvi, Shah Wali-Allah, 294.
} 
Tabarrā often means the shouting of curses on Satan, but in the Shīi context, it refers to the widespread ritualised practice of condemning the first three successors of the Prophet and other figures such as his wife 'Â'isha and the first Umayyad caliph, Mu'āwiya. Aiming at the dissociation from the enemies of the ahl-i bayt (household of the Prophet), this ritual is sometimes followed by the public burning of those figures' effigies in the streets and the bazaar. It is highly resented by many Sunnīs and has time and again provoked sectarian riots and spontaneous violence between Sunnīs and Shīīs in South Asia. ${ }^{17}$

The Naqshbandī reformist Mazhar Jān-i Jānān, the head of the central Naqshbandī convent (khānaquahh) in Delhi from 1747 until his death and the founder of the Shamsiyya-Mazhariyya branch of this order, sought to reduce conflict both among the Sunnì legal schools (madhähib) and between Sunnīs and Shīiss. Born into a noble family of Afghan origin which served in the Mughal administration, Mazhar had attended several masters of different brotherhoods but was mostly attracted to the Naqshbandiyya-Mujaddidiyya. He considered the respect for the companions of the Prophet not as an essential part of faith, and advocated the inclusion of Shīiss within the fold of Islam due to their confession (shahāda) of the unity of God. ${ }^{18}$ However, with the renewed prominence of Shīiss in the court in 1781, Mazhar, too, allegedly made some derogatory remarks against the public mourning ceremonies for the death of Ḥusayn b. 'Alī and was apparently assassinated by Shī‘̄i zealots. ${ }^{19}$

Another Mujaddidī Sufi thinker and fighter, Sayyid Ahmad of Rae Bareli (d. 1831), who also called his way Țariqa Muhammadiyya, pursued a more radical reformist agenda and is best known for his jihäd against the Sikhs and his advocacy of a version of Islam which was purged of Hindu influence. He also criticised Shīi 1 practices, along with the Sufis' belief in the intercession of their masters (pirs). He identified false Sufism, Shīism, and errant popular customs as the sources of religious corruption and hence declining Muslim power. According to him the refutation of Shicism was a necessary part of the revival of Islamic power in India and it was required for the reform campaign designed to restore Muslim belief and practice to their originally intended condition. ${ }^{20}$ It should be mentioned that in this time, besides India, other parts of the Islamic world also witnessed the emergence of anti-Shi'i reformist tendencies. The movement of Muhammad b. 'Abd al-Wahhāb (d. 1792)

17 Hyder, Reliving Karbala, 82.

18 Weismann, The Naqshbandiyya, 65-66; Friedmann, "Medieval Muslim Views".

19 See Dahnhardt, Change and Continuity, 14-41; Umar, "Mirza Mazhar Jan-i Janan".

20 Nasr, The Shi'a Revival, 99-100. For Sayyid Ahmad's reformist thought and practice, see also Rizvi, Shah 'Abd al-'Aziz; Gaborieau, Le Mahdi incompris. 
condemned Shīism as part of its efforts to revive and reform Islam. In 1802, Wahhābīs, who considered the veneration of shrines as a form of polytheism and viewed Muslims engaged in these acts as heretics, attacked Karbala and destroyed and plundered the shrine of Husayn b. 'Alī. ${ }^{21}$

\subsection{Polemical Literature}

In the course of these political and religious tensions, polemical literature was produced in the forms of learned theological treatises, popular polemical tracts, poetic invectives, and satire by both Shīì and Sunnī scholars and poets. In the latter part of his life, Walī Allāh wrote two works, Izālat al-khafä' 'an khiläfat al-khulafä' (Removing secrecy from the issues concerning the caliphate) and Qurrat al-aynayn fi tafdill al-shaykhayn (Delight of the eyes on the superiority of the first two caliphs), which addressed Shīi ì claims concerning the nature of the caliphate and the superiority of 'Alī. Although in his works Walī Allāh refrains from using the word $k \bar{a}$ fir (infidel) in referring to Shī'ss, he claims that the Shīi madhhab was bățil (false, void). According to his main argument, the belief in the ișma (infallibility) of the Twelve Imams is incompatible with the finality of prophethood, even though in his Tafhimāt al-ilähiyya (Divine instructions) he himself attributes a kind of ișma - along with the three other qualities of hikma (wisdom), wajāha (prestige, excellence), and quțbiyyat-i ba ținiyya (the position of a hidden spiritual pivot) - to the Imams. ${ }^{22}$ In 1731-32, Walī Allāh translated Aḥmad Sirhindī's (d. 1624) Radd al-rawāfị (Refutation of the Shīis) into Arabic and added his own foreword to it; it was apparently the main text refuting Shīi positions in the late sixteenth and throughout the seventeenth centuries. Similar polemical issues can also be found in his other writings. ${ }^{23}$

Walì Allāh's discussions of Shīì ideas and practices were followed by Tuhfa-i ithnā 'ashariyya (The gift to the Twelver Shīiss), which was written by his son, 'Abd al-'Azìz, in 1789-9o. Divided into twelve chapters, representing the number of Shīì Imams, the work aims to comprehensively refute Shīî beliefs and practices. Aside from the origin of the Shīì denomination and its concepts of divinity, prophethood, and jurisprudence, it deals with themes such as the precedence of 'Ali or of the first two caliphs, the cursing of the Prophet's companions, the tradition of 'Umar's denying the Prophet's wish for pen and paper, and

\footnotetext{
21 Wynbrandt, A Brief History, 135.

22 Walì Allāh, al-Tafhìmāt, 14.

23 Umar, Islam in Northern India, 254.
} 
'Alī's several marriages and his judiciousness. ${ }^{24}$ In his Sayf Allāh al-maslūl 'alā mukharribì dìn al-rasūl (The drawn sword of God against those who destroy the religion of the Prophet), Mīrzā Muhammad Akhbārī (d. 1816), the jurist, hadìth scholar, poet, and pillar of the Akhbārì movement in India, was among the first Shīīs who attempted to respond to the Tuhfa. Then, Sayyid Dildār 'Alī $\left(1753^{-1820}\right)$, the chief mujtahid of the state of Awadh, together with his students wrote a series of treatises in response to it, each of which was devoted to an individual chapter of the Tuhfa; al-Șawārim al-ilāhiyya (Divine thunderbolts) was thus written in response to its sixth chapter; Husām al-Isläm (The sword of Islam) was a rebuttal of the fifth chapter; and Khätimat al-șawārim (The end of thunderbolts) a refutation of the seventh. Sayyid Ḥāmid Ḥusayn (1830-88), a student of Dildār 'Alī, also published eighteen volumes under the title Abaqūt al-anwār fi imāmat a'immat al-athār (Fragrant blossoms on the imamate of the pure imams), taking a stance against not only 'Abd al-'Azīz but also other Sunnī critics of Shī'i positions. ${ }^{25}$

Shīīi-Sunnī polemical texts started to be produced in India centuries before 'Abd al-'Azīz and Dildār 'Alī. Sirhindī wrote his anti-Shīī treatise Radd al-rawāfid in 1008/1599-160o. In 1587, Qāḍi Nūr Allāh's Mașāib al-nawāṣib (Calamities of the Sunnīs) was a reply to Mirzā Makhdūm Sharī's (d. 1587) al-Nawāqid fì l-radd 'alā l-rawäfid (Nullifiers on the refutation of Shīis) in Baghdad, which was soon brought to India and circulated there. Qāḍi Nūr Allāh also wrote al-Ṣawārim al-muhriqa (Burning swords) in reply to the Șawāiq al-muhriqa fí l-radd 'alà ahl al-raf̣̂ wa-l-daläl wa-l-zandaqa (The burning thunderbolts in refutation of the people of refusal, error, and heresy) of Ibn Hajar al-Haytamī (d. 1566-67) and Ihqāq al-haqq (Realisation of the truth) in 1605 in refutation of Fathuullāh Ruzbihān's Ibtāal al-nahj al-bāțil (Invalidation of the false path) (1503).

\subsection{Dard and 'Andalīb}

It is within the above-explained Indian context of Sunnī-Shīì relations - that is, the competition over power during the establishment of new Shī'i principalities, the renewed patronage of Shīi rituals and seminaries by certain rulers, and the ensuing sectarian conflict and polemics - that the prominent eighteenth-century mystic of Delhi Khwāja Mīr Dard conceived a doctrine

24 See 'Abd al-'Azīz, Tuhfa, 416-537; for the polemic thought of Shāh 'Abd al-'Azīz, see also Rizvi, Shah 'Abd al-'Aziz.

25 Ṭabāțabāìi, "Mawqif al-shī'a", 41, 52. 
which was to lead, in his view, beyond the Shīì and Sunnī frameworks, a path encompassing both creeds, called in his parlance țaríqa jämi'a ("comprehensive way"). ${ }^{26}$

Both Mīr Dard and his father, 'Andalīb, were prominent Sufi theologians, poets, and musicians in Delhi, which was still the centre of the Mughal Empire. ${ }^{27}$ Moreover, they belonged to the reformist Naqshbandī-Mujaddidi circles. Dard had studied Islamic sciences such as law and hadith, though explicitly separating himself and his approach from the traditional ulam $\bar{a}$ and their viewpoints. ${ }^{28} \mathrm{He}$ was the theoretician and exponent of the Tariqa Muhammadiyya Khālișa initiated by his father, 'Andalīb, who himself was a disciple of one of Sirhindì's immediate descendants, Pīr Muhammad Zubayr (d.1740). 'Andalïb was the first Indian to call his Sufi path Țarīqa Muhammadiyya, a designation which, as we have seen, was later used by Sayyid Ahmad of Rae Bareli. ${ }^{29}$ In Dard's view, his father was among the saints of the Muslim community who had appeared to renew (tajdid) and revive (ihy $\vec{a})$ the pure religion of God, after it had become contaminated by innovations and the Muslims' deviation from the Prophet's original tradition. For him, 'Andalīb had been sent by God ultimately to proclaim the only way of salvation and the most perfect manifestation of the truth. ${ }^{30}$

Dard's major contribution, among other works, is his Ilm al-kitāb (The knowledge of the book). Besides reflecting on a variety of religious and cultural themes and theological, legal, and philosophical debates of the late seventeenth and early eighteenth centuries, the book contains some idiosyncrasies (such as those related to Shīism) which distinguish it from the reform-oriented texts of his contemporaries. Among the latter were works like Hujjatullāh al-bāligha (The conclusive argument of God) by Walī Allāh and the Maqāmāt-i Mazharī (Exempla of Maẓhar) of Mīrzā Maẓhar Jān-i Jānān ${ }^{31}$ that was compiled by Shāh Ghulām 'Alī (d. 1824), who at the age of thirteen had associated with Dard in Delhi. ${ }^{32}$

26 For details on the tarīqa jāmica, see Khodamoradi, "Tarīqah Muhammadiyyah"; Khodamoradi, Sufi Reform, 127-62.

27 On Dard as a poet, see Dard, Urdū dīwān; Dard, Dīwān-i fārssī; Schimmel, Pain and Grace, 31, 49; Ziad, "I Transcend Myself".

28 Dard, Chahār risāla, 219.

29 Schimmel, Pain and Grace, 33. See also Ahmad, Saiyid Ahmad Shahid; Gaborieau, Le Mahdi incompris.

$30 \quad$ Dard, $T / m, 587$.

31 The latter work consists of the letters and Sufi discourses (malfüzāat) of Mīrzā Maẓhar Jān-i Jānān.

32 Storey, Persian Literature, 1034. 
As an extensive commentary on 111 wāridāt written in quatrains, ${ }^{33} \mathrm{Ilm}$ al-kitāb is a highly technical theosophical-theological text that highlights several problems of its time. These include discussions over the interpretation of holy scripture ( $t a^{\prime}$ wìl) and the distortion of its meaning (tahrī $)$ ); debates on the authoritative sources of knowledge and faith; and the search for a comprehensive Islamic knowledge. The book also tackles social challenges such as the issue of religious authority, which Dard bases on blood affiliation with the Prophet (siyāda), in combination with a spiritual union with him. It also deals with the sectarian conflicts between Sunnīs and Shī̄is, to which the author dedicates a significant part of his theological discussions, reconstructing the theoretical bases of such denominational differences.

In Ilm al-kitāb, Dard not only reconsiders some of his forefather's influential teachings, such as Sirhindì's devaluation of the doctrine of the "unity of being" (wahdat al-wujūd) and his advocating the notion of the "unity of witnessing" (wahdat al-shuhūd), ${ }^{34}$ but also makes radical amendments to the Mujaddidi Sufi scholars' mostly hostile approach to Shīism. In his reconsideration of Shì'ism, he follows the goals prescribed by his father in the latter's introduction to Nāla-yi 'Andalīb. Nāla is a voluminous book of approximately 2,00o folios written in Persian and containing an interpretation of a story that was originally narrated by 'Andalīb in Hindi over a period of three nights in memory of Pīr Muhammad Zubayr, who had just died. 'Andalīb expanded upon this story, adding a number of subplots into the framework of the main narrative, and used the now extensive tale as a way to explain his Muhammadan Path. ${ }^{35} \mathrm{He}$ also inserted Hindi dohas (a genre of Hindi explanatory poetry generally used in epics) into the story and referred to Hindu philosophy and customs. ${ }^{36}$ In $N \bar{a} l a$, 'Andalīb explains the aim of his book as being to propose a path free from all of the uncertainties and problems found in various sects of Islam. He refers to the high curiosity among the younger generation about the truth within the Shī'i and Sunnī branches of Islam: "Brothers of the path would ask me about issues of the path that came to mind ... Young men would often ask me about the realities of the Sunnī and Shīì schools."37 'Andalīb tries to establish a plausible framework, that is, the Tariqa Muhammadiyya, for all religious and societal strata and for every aspect of life, as a way applicable for Sunnīs and Shīīis, men and women, the elite and folk, with worldly and otherworldly benefits alike. ${ }^{38}$

33 Dard, Tlm, 91-96, 473; Dard, Chahār risāla, 6.

34 Dard, $T / m, 3-5$.

35 Saghaeearaj, "Muḥammad Nāṣir 'Andalīb".

36 'Andalīb, Nāla, 1:789, 813, 882, 2:712, 900.

37 'Andalīb, Nāla, 1:3.

38 'Andalīb, Nāla, 1:4. 'Andalīb deals with Shīīi imamology in his Nāla, 2:583. 


\subsection{Siyāda and Imamate: Solutions for the Conflict and Polemics}

Following his father, Dard's addressees are all types of Muslims, be they traditionalist or rationalist, Sufi or scholar, Shīi ì or Sunnī. ${ }^{39}$ In contrast to the approach of Walī Allāh, his synthetic attempt does not exclude the Shīì doctrine. To include Shī'ism in his own way, Dard utilises, among other subjects, the significant concept of siya da which is associated with that of the imamate. Siyāda is one of the two main pillars - the second being direct mystical connection with and annihilation in the Prophet ( $\operatorname{ann} \bar{a}^{3} f \bar{l} l$-ras $\left.\bar{u} l\right)$ - on the basis of which Dard constructs his ultra-Sunni-Shīī way of the Țariqa Muhammadiyya Wãthiqa. It is in reference to the fundaments of siya $\bar{d} a$ and the imamate that Dard called himself a sayyid, a member of the Prophetic family and an offspring of the Prophet's daughter Fāțima, ${ }^{40}$ rather than a saint or shaykh or Sufi (see already above). The first parts of his name, Khwāja and Mīr, refer to this sayyid origin from both maternal and paternal sides. ${ }^{41}$ In his pure Muhammadan Path, siyada retains its function as one of the crucial sources of religious authority.

Dard reconsidered the challenging subject matters between Sunnīs and Shīiss circulating around the importance of blood affiliation with the Prophet. In his approach to the long-term dispute over the exalted status of the family of the Prophet (ahl-ibayt) in Shí'ism and on that of Muhammad's companions (șahāba) in Sunnì tradition, Dard, despite his Sunnì background, places the progeny of the Prophet at a higher rank than his companions. Using a simile, he likens the Prophet to a tree whose main branches are his progeny, due to their blood relationship with him, whereas the companions are branches cut from other trees and transplanted onto the Prophetic one. ${ }^{42}$ Elaborating on the rank of the ahl-i bayt, Dard adds that members of the Prophet's household are joined to Muhammad both by virtue of being his companions and by being his offspring, therefore encompassing all exterior and interior perfections and virtues. ${ }^{43}$

Dard also considers his father and himself as belonging to the main branches of the Prophetic tree due to their being najib al-tarafayn (highborn through blood affiliation with the Prophet via both parents), thus possessing both exterior and interior perfections. He calls his father "the veritable sayyid and most righteous imam, who is the helper of the nation and the religion".44

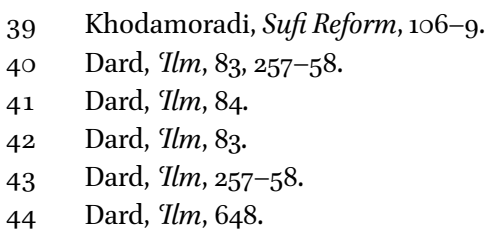


Having emphasised the superiority of Muhammad's progeny over his companions, Dard warns his audience not to consider him as an advocate of afdaliyya ("precedency"), a Shi'i concept referring to the preference of the accomplished and learned for leadership over the unaccomplished and unlearned. Afdaliyya is related to the polemical issue of the leader's required characteristics in Islamic theology. According to Shīi theologians, an imam has to surpass other Muslims in two aspects in order to obtain the requirements of leadership: (a) his proximity to God and in the level of divine rewards that he enjoys; and (b) the characteristics which relate to human perfection such as bravery and knowledgeability. Thus, according to this point of view, prioritising less learned Muslims over those who are more learned is impossible..$^{45}$ This argument is used in polemics over the caliphate by Shīìs, who argue that 'Alì was more knowledgeable than the first Sunnī caliphs and therefore the true successor of the Prophet. Sunnī scholars, in turn, consider the hadith references that form the basis for the theory of afdaliyya as weak or categorise them as fabrications. ${ }^{46}$

Dard argues that, despite his emphasis on the originality of the Prophet's progeny - and consequently the Imams - as the main branches of the tree, they are equal to the companions in terms of their function. To him, both groups, like both types of branches, provide fruit as well as pleasant shade and beauty for the Muslims, and Muslims should only be concerned with these benefits and nothing else. Emphasising that both descendants and companions, whether natural or transplanted, are after all branches of the same tree, he accentuates that the resort (tawassul) to each companion and Imam becomes a resort to the Prophet himself. ${ }^{47}$ In this way, Dard stood firm on the comprehensiveness of the pure Muhammadan Path, without being diverted from his Sunni position regarding the value and status of the companions. This was his approach to build a bridge between the Shīì and Sunnī denominations, which his father had already started to construct in his Näla.

Dard introduces himself as the heir of the ahl-i bayt and of the continuous chain of the imamate. He even attributes to himself the revolutionary title of a "missionary imam" (imām-i $d \bar{a} \bar{c}$ ), who invites people to the comprehensive pure Muhammadan Path, ${ }^{48}$ and announces the authority of his way as a hereditary power (dawlat-i mawrūthī).$^{49}$ Dard considers the Ṭariqa Muhammadiyya

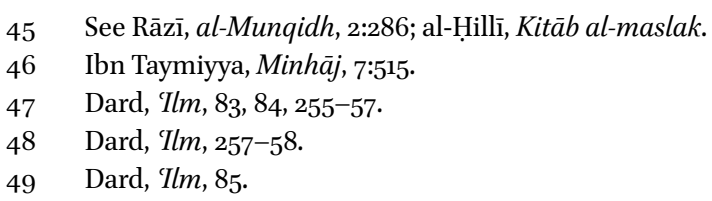


as the continuity of the imamate and the receptor of the knowledge that has disappeared after the eleventh Imam, al-Hasan al-'Askari (d. 874). This marks its differentiation from the other Mujaddidī currents such as the Mazhariyya and the followers of Walī Allāh, whose genealogy goes back to Abū Bakr and who concentrates on the caliphate rather than the imamate in his discussion of Muslim leadership. Arguing for the inclusion of Shīiss in his broad project of the Tariqa Muhammadiyya, Dard interprets and elaborates on a variety of hadiths such as the hadith al-thaqalayn ("hadith of the two weighty things"), hadith al-ghadir ("hadith of the pond"), and those Prophetic sayings that refer to 'Alī as the most authentic source of knowledge, ${ }^{50}$ hadìths that had formed the theological foundations of Shīī theology for centuries. Considering 'Alì's knowledge as of the highest order, Dard does not explicitly speak about his role as a source of Islamic law and regulations. However, his frequent uses of the set of the Qurān, haditths, and the imamate gives the impression that, besides his effort to establish the Tariqa Muhammadiyya based on the spiritual knowledge of the imamate, he also intended to give some impulses towards a reconsideration of the Sunnī sources of Islamic law. The above-mentioned hadīths, narrated frequently in Shīī sources and also often mentioned in Sunnī collections (though with some textual variations), ${ }^{51}$ had played a crucial role in Sunnī-Shīì disputes for centuries. Several scholars of both communities had continued to reconsider and reinterpret them, while continuously arguing for and against their authenticity. ${ }^{52}$

One category of hadiths described by Dard is related to the friendship (mawadda) and love (mahabba) of the household of the Prophet, ${ }^{53}$ for instance: "Whoever does not love 'Alī is a hypocrite and whoever does not hate him is faithful. And whoever is far from this threshold is far from the city." ${ }^{\prime 5}$ The veneration and love of the ahl-i bayt has always been a part of Sunnī

50 The hadith al-thaqalayn reads thus: "I [Muhammad] leave among you two things, and if you strictly adhere to them, you shall never go astray: The Book of Allah and the people of my house (ahl-i bayt). I have told you that you will reach me in heaven at the pool [of al-kawthar] and I will ask you about how you behaved with those two valuable relics" (Kulaynī, al-Ușūl, 1:294). In the hadìth al-ghadìr, Muhammad states: "To whomever I am master ['friend' in Sunnī interpretation], 'Alī also is his master." In volume 7 of 'Abaqāt al-anwār, the author discusses this hadīth and its various narrations by Sunnī scholars. See Mīr Ḥāmid, 'Abaqāt, vol. 7 .

$51 \quad$ Dard, $T l m, 255$.

52 Among the hadìths narrated by Dard which are also mentioned by Sunnī hadìth scholars are (a) "Fāṭima is a part of me, whoever harms her harms me" (Bukhārī, al-Jāmi'al-ṣahịh, 4:292-94) and (b) "Alī and I are from one light" (Ibn al-Maghāzilī, Manāqib, 17).

53 Dard, $1 / m, 259,260$.

54 Dard, $\mathrm{Tlm}, 255$. 
tradition, too, even though it never reached the centrality as in Shīi religiosity. In Shi'ism, by contrast, the intense love for the Imams and the household of the Prophet permeates the worldview of believers and influences the structure of their religiosity. Expressing one's love for his descendants through devotion to them, following them, and assisting and protecting them from any harm and distress are among the criteria used to determine the integrity and soundness of one's faith and actions. In other words, it has become a way in which one is able to attain salvation. Numerous hadīths in early Shī'ì writings highlight this love and list it as a criterion for the validity of one's faith whereas enmity towards the Imams is regarded as a sign of unbelief. ${ }^{55}$ However, there is also a certain consensus among both Sunnīs and Shīīs that love and respect for Muhammad and his progeny are mandated by the Qurān and the Prophetic tradition, and several Sunnī hadith scholars have narrated hadiths to that effect. ${ }^{56}$ Emphasising this consensus, Dard, in line with Shīiss, considers the love of 'Alì as the criterion of faith (mahakk-i imān), and deviation from it as the sign of hypocrisy and failure. ${ }^{57}$ 'Alī is described by him as the owner of faqri Muhammadī ("Muhammadan poverty"), and a person who is united with the Prophet (lahu nisbat al-'ayniyya bi-l-rasūl) and his flesh and blood is the flesh and blood of the Prophet. ${ }^{58}$ Referring to the hadìth "Fāțima is a part of me: whoever harms her, harms me", Dard likens the relationship of the ahl-i bayt and sādāt with the Prophet to the relationship between an individual's limbs and his self. He concludes that the love of the ahl-i bayt and the Imams is the love of the Prophet himself, because to love the limbs or individual parts of a person is nothing but to love that person, and to hate them is to hate that person. ${ }^{59}$ He even affirms a kind of ișma (infallibility) for the ahl-i bayt and declares that they are sublime essences (dhawāt 'aliyyāt) with a pure and sacred nature. They are absolutely pure in the exterior as God purified ('așama) them from all sins, and also in the interior, as He protected them from all temptations and unbidden thoughts (wasāwis wa-hawājis). ${ }^{60}$

It was, most probably, this unusual attempt by Dard to strongly underline the role of the ahl-i bayt and the Imams in his Tariqa Muhammadiyya doctrine that earned him criticism from the Sunnì Muslims of his time. Even some of his own followers accused him of an unlawful innovation with his foundation

Mavani, Religious Authority, 40-1; Madelung, The Succession to Muhammad, 13.

56 For example, see Sharif, trans., Șậḥ Muslim, 1:126.

57 Dard, 'Tlm, 255.

58 Dard, $1 / m, 257$.

59 Dard, $T l m, 255$.

6 Dard, Ilm, 83 . 
of a new way (tariqa muhdatha). ${ }^{61}$ They had apparently criticised him for his Shīi tendencies and for his sole focus on the degrees and features of the ahl-i bayt. In reaction, Dard admits that they are correct and sound, stating that he deals primarily with the ahl-i bayt and their excellence but does not dwell upon the virtues and greatness of the companions. He explains, however, that the excellence of Abū Bakr and 'Umar are clearer than the sun, that their bliss ( fuyū $\bar{a} \bar{t}$ ) which exudes from them has covered the whole world, and that there is thus no need to explain it. Moreover, he continues, most of the Sunnī scholars had stated the greatness and perfection of the companions but had not dealt with the biography of the ahl-ibayt to the extent that they deserve:62

I tried to deal with the subject of the ahl-i bayt in order to make the Sunnīs respect them and love them, too ... The Sunnīs have not written about their ranks (maqāmāt) as much as they deserve.... I speak about the Prophet's progeny to help Sunnis also to benefit from the grace of proximity to the imamate (qurb-i imāma) ... My aim is to quell the fire of prejudice among both Shīis and Sunnīs and invite them to join the path of balance (i'itidāl).

Dard continues that his aim is not to prefer one party over the other, as those Shīīs who believe in precedence (tafdīliyān) or prejudiced Sunnīs do. ${ }^{63}$ Although Dard incorporates an important element of Shīī belief in his Tarīqa Muhammadiyya doctrine, he strongly maintains his Sunnī and Ḥanafî foundations, and his definition of the ahl-ibayt also includes the Prophet's wives such as 'Â'isha, a challenging personality to the Shīì worldview. However, he emphasises the importance of Fātima, 'Alī, Ḥasan, and Ḥusayn as the main members of the Prophetic progeny and the possessors of the highest rank among the ahl-i bayt, by stressing hadiths such as "Ali and I are from one light" and "the dearest among my people to me is Fāțima and the dearest among my ahl-i bayt are Ḥasan and Ḥusayn".64

Trying to establish a balance between Shīī tendencies and Sunnī faith, Dard asserts in his works that there is a differentiation between his own loving attachment to the Prophet's household and that of those Shī'ss whom he calls rawäfid ("rejectors", or heretics). The latter is a derogatory term oftentimes used by Sunnīs for Shī'iss who curse the first three caliphs, Abū Bakr, 'Umar, and

\begin{tabular}{ll}
\hline 61 & Dard, Tlm, 262. \\
62 & Dard, $T / m, 256$. \\
63 & Dard, Tlm, 256. \\
64 & Dard, Tlm, 255.
\end{tabular} 
'Uthmān, in order to express their rejection of them as the legitimate successors of Muhammad. ${ }^{65}$ The rawäfid's affection, according to Dard's viewpoint, reflects the "ignorant love" of common people that damages guidance.

It is unlikely that he refers with this derogatory term to Shīis in general. In contrast to his Naqshbandī contemporaries Walī Allāh and his son, 'Abdul 'Azìz, Dard rarely criticises common Shīìs and neither denounces nor mentions Shīi rituals such as the commemorations of Muharram or the taziya. Thus, his use of the humiliating term rawäfid most probably singles out only those Shīis who do not fit into the framework of his Țariqa Muhammadiyya that considers both Imams and companions of the Prophet as branches of the same tree of prophethood. His use of this term may also just be a kind of concomitance with the prevailing anti-Shīa sentiment among Sunnīs of his time. It furthermore points to his invitation of the Shīis to adopt his model of the Muhammadan individual, who has stepped beyond Sunnīs and Shīiss. That is why he explicitly calls on Shīīs to join the Muhammadan Path, with siyāda and imamate as central pillars.

It is not only the narrative of love for the ahl-i bayt that was underlined by Dard. He also concentrates on the concept of the imamate while remaining in his Sunnī-Hanafì-Mujaddidī framework of the Taríqa Muhammadiyya. He did so exactly at the time when Wali Allāh was constructing a theory of khiläfa (viceregency of the Prophet) in which the era of the first Shìi Imam, 'Alī, was denounced as the age of fitna (rebellion). To this end, Dard focuses on other hadiths which were significant for the question of the imamate as the highest source of knowledge directly revealed from God ('ilm-i ladunni), after the knowledge of prophethood (nubuwwa). He mentions, for instance, the hadīth: "I am the city of knowledge and 'Alī is its threshold." ${ }^{66}$ With regard to this hadith, Dard stresses the role of 'Ali as the transmitter of knowledge within the lineage of the imamate via Fāțima's offspring, notably Ḥasan and Husayn, and not via other sons of 'Alī born from his other wives. ${ }^{67}$ In this way, he differentiates between the sādāt of Banī Fāțima and other 'Alawī sādāt who descended from 'Alī through his three sons, Muḥammad b. al-Ḥanafiyya from Khawla bt. Jacfar al-Ḥanafiyya, 'Abbās from Umm al-Banīn, and 'Umar from Șahbā’ al-Taghlibiyya.

\footnotetext{
65 Rāzī, Itiquādāt, 59.

66 Shī'is believe that 'Alì is the most knowledgeable person after the Prophet. Among Sunnī scholars, Ibn Taymiyya clearly states that nobody from the ahl al-sunna agrees with this idea and there is a strong consensus among Sunnī theologians that Abū Bakr and 'Umar are the most knowledgeable people after the Prophet (Ibn Taymiyya, Minhāj, 4:5, see also 7:500-28).

67 Dard, Ilm, 259ff.
} 
Focusing on the connection between siya $\bar{d} a$ and the imamate, Dard states that the chain of the imamate did not stop with the death of the eleventh Imam but continued via the siya $\bar{a} a$ of the Prophetic offspring which included Dard's father and himself. ${ }^{68}$ Dard even attributes to himself the title of "son of the Imam" when he stresses his own countless titles and beautiful names, such as the knower ('âlim), the light (nūr), the hearer (samī), the one (wahìd), and the patron $($ wali $){ }^{69}$

Dard's reference to himself as "son of the Imam" is partly due to his father's title, who was considered by Dard and most probably also by his other disciples as "Imam of the gnostics" (Imām al-ärifin). For him, 'Andalīb was the heir of 'Alī's knowledge (wärith-i 'ilm-i murtadawī) and manifested the lights and bounty of the imamate due to his descendance from the Prophet. ${ }^{70}$ Dard emphasises that the imamate continues until the Day of Judgement through those carrying the blood of the Prophet and his progeny. ${ }^{71}$ According to him, each era witnesses somebody who is endowed with the grace of the imamate and honoured with the hereditary bliss ${ }^{72}$ that makes Muhammad reappear through his progeny, until his final reappearance in the Mahdī (the last manifestation and representative of Muhammad). ${ }^{73}$ Because of this reappearance, the way in which people treat the sādāt of the Muhammadan Path is considered as their treatment of Muhammad himself, since the Prophet's progeny are empty of their own identity and carry the real existence of Muhammad: "Their soul is the soul of Muhammad; their faith is the faith of Muhammad; their flesh and skin is the flesh and skin of Muhammad; their home is the home of Muhammad; and their time is the time of Muhammad."74

For Dard, God made the sādāt the owners of time and gave them his command to call Muslims to the Tariqa Muhammadiyya Khälișa. ${ }^{75}$ They enjoy the specific knowledge of the imamate, ${ }^{76}$ the "divine Muhammadan knowledge" ('ilm-i ilăhīi muhammadī), and the status of the most intimate proximity

\footnotetext{
68 Dard, Ilm, $259 \mathrm{ff}$.

69 Dard, $T / m, 62$.

$70 \quad$ Dard, $1 / m, 137$.

71 Dard, Tlm, 259-6o, 264, 611, 613.

72 Dard, $1 / m, 257,260$.

73 About the finality of the Tarīqa Muhammadiyya Khālișa in the time of the Mahdī, see Dard, $T / m, 85$.

74 Dard, Tlm, 259 .

75 Besides reinforcing blood kinship through propounding siyanda and the imamate, the Tariqa Muhammadiyya claims its validity through 'Andalīb's mystical vision of the second Shīîi imam, Imam al-Ḥasan (Dard, Tlm, 85).

76 Dard, $T / m, 257,26$ o.
} 
(qurb-i akhașs al-khāṣș) granted by God. ${ }^{77}$ Elaborating on what he means by such knowledge, Dard here points to the above-mentioned hadith that declares "Ali to be the gate or threshold leading to the "city of knowledge" and in this way presents him as a mediator without whom the knowledge of God cannot be achieved. ${ }^{78}$ This hadith has been considered by many Sunnì scholars, including Aḥmad b. Ḥanbal (d. 855), Bukhārī (d. 870), Tirmidhī (d. 892), Ibn Hibban al-Bustī (d. 965), Dhahabī (d. 1348), and Ibn Taymiyya (d. 1328), to be either weak or fabricated both in transmission and wording. ${ }^{79}$ Dard, however, largely bases his concept of the Muhammadan knowledge on it, without discussing its diverging status in Sunnī and Shīīi theological traditions.

Dard divides knowledge ( $i l m$ ) into two categories: (i) intellectual ('aqlī) knowledge, which encompasses the sub-branches of theology, mathematics, and natural sciences; and (ii) divine knowledge, through revelation and inspiration (ladunnī or wahb $\bar{\imath}$ ), which is itself divided into the following types: (a) prophecy and (divine) message (nubuwwa wa-risāla), both of which are mediated by the angel Gabriel (Jibra'il) and cause divine proximity (taqarrub). This knowledge is related to the reform of life in this world and in the hereafter (umūr-i mușlih-i ma'äsh wa-ma'ād) and was completed and finalised by the Prophet Muhammad; (b) knowledge of the caliphate (khiläfa) that was achieved through inspiration (ilhäm), along with the rightful demand to receive allegiance (akhdh-i bay'a), in the first thirty years after the time of the Prophet. It is also related to the affairs that reform life in both worlds; (c) the knowledge of the perfections of prophethood (kamālät-i nubuwwa), which was again achieved through inspiration by Muslims other than the Prophet's offspring and began thirty years after the Prophet's death. It includes issues that reform both lives, as well; (d) the knowledge of the imamate (imāma), which was achieved through inspiration but only by the offspring of the Prophet, along with the right of allegiance, after thirty years had passed since the death of the Prophet and also in later times. This, too, conveys the affairs that reform life in both material and spiritual spheres; (d) the knowledge of sainthood (wilāya) and its sub-branches of the "unity of being" and the "unity of witnessing" (wahdat al-wujūd wa-wahlat al-shuhüd); (e) Sufism (tașawwuf); and (f) religion $(\operatorname{din}) .80$

77 Dard, Ilm, 61o. For divine Muhammadan knowledge, see Khodamoradi, Sufi Reform, 153-6o.

78 Dard, $T l m, 255$.

79 For the list of Sunnī scholars challenging the authenticity of this hadìth, see Bin Arḥama, Takhrï, 7-8.

8o Dard, $1 / m, 82$. 
Among these categories, the knowledge which lies in the imamate ('ilm-i imāmat $)^{81}$ stands out as a particular wisdom that differs from and is higher than all the others after the knowledge of prophethood. Similar to the knowledge of prophethood, of the caliphate, and of the perfections of prophethood, 'ilm-i imāmat pertains to matters that reform life in this world and in the hereafter and culminates in the proximity to the Divine. It shares common elements with the aforementioned types of knowledge such as inspiration and right of allegiance but differs from them through its particularity of being the prerogative of the Prophet's offspring. It also went along with their rightful demand for allegiance, which set in thirty years after the death of the Prophet with the caliphate of his grandson Hasan, to whom many Muslims swore the oath of allegiance after the death of his father, the fourth caliph, 'Alī b. Abī Taalib. According to Dard, allegiance to Ḥasan was the starting point for the leadership of the Muslim community by the offspring of the Prophet, that is, the Imams and descendants of Fātima. Rejecting the Shīì narrative of fitna (sedition) that considers the first three caliphs as usurpers, he explicitly accepts the caliphates of Abū Bakr, 'Umar, and 'Uthmān. Only for the period after the four rightly guided caliphs Dard reserves both worldly and spiritual leadership, and the position as valid sources of knowledge, to the Imams and descendants of Fāțima. The Muslims' allegiance to Hasan as the fifth caliph plays a key role in his definition of the knowledge of the imamate. Thus, in Dard's view, the blood of the Prophet and the knowledge of 'Ali provide the framework of leadership of the Muslim community with both of them now existing in their purest form in the founders of the Țariqa Muhammadiyya Khāliṣa.

Ilm-i imämat is a knowledge that connects the finality of the prophethood with the continuity of the imamate. According to Dard, the Prophet Muhammad is a person who has traversed all degrees of perfection to the end, and it is only the Prophet's bliss and the manifestation of his perfections that have been continuing - and will continue - through his offspring, ${ }^{82}$ who, on their part, encompass all types of perfections and virtue, both exterior and interior. ${ }^{83}$ Dard insists that his Muhammadan Path is different from the Mujaddidīs whom he sees in analogy to the Prophet's friends and companions. The Muhammadīs, by contrast, represent the very limbs, hands, and feet of Muhammad. He even asserts that the "sādāt of the Țariqa Muhammadiyya enjoy the 'total unity' ('ayniyyat-i tāmm) and 'the total annihilation' ( fan $\bar{a}^{3}-i$

81 On the imamate, see Dard, Tlm, 259.

82 Dard, Tlm, 257, 263-64.

83 Dard, $T / m, 257$. 
atamm) in Muhammadness", which is why they are considered special (khāsș.$^{84}$ The title Taríga Muhammadiyya Khāsșa, which Dard uses in reference to his way, illustrates the particularity which makes the mystical experience and rank of the "pure Muhammadī" (Muhammadi-i khäliṣ) the highest experience related to the Prophet Muhammad. It differs for him from that of the "perfections of prophethood" (kamālāt-i nubuwwa), a significant mystical experience and rank in the Mujaddidiyya that is equal to general prophethood (nubuwwat-i 'âmma).

According to Dard, this rank of the "pure Muhammadī" belongs to the family of the Prophet in particular, whose members are sublime essences coming into existence through the rays of Muhammadan light and have the potentiality of Prophetic mission. But he believes that pure Muhammadness will continue forever and that all Muslims can achieve this stage and enter this țariqa. It exists as a potential in each and every Muslim, though its most powerful point will only be achieved in the time of the Mahdī, when the whole world will be enlightened with a unique light of pure Muhammadness. ${ }^{85}$

Dard declared that knowledge connected with the imamate went into hiding after al-Hasan al-'Askarī (the eleventh Shīi Imam who died around 874) and was rediscovered in the eighteenth century by his father, 'Andalīb, who passed its secrets to Dard. Dard himself continued 'Andalīb's call for the revitalisation of the religion by descendants of the ahl-i bayt. ${ }^{86}$ His emphasis on the continuity of the Prophetic mission through the imamate, rather than the continuity of wilāya (sanctity and spiritual leadership) through Sufi masters, makes Dard's approach towards the knowledge and genealogy of the Tariqa Muhammadiyya significantly different from that of established Sufism.

\subsection{Conclusion}

In the sociopolitical conflict and the polemical controversies between Sunnīs and Shī iss that were ignited in eighteenth-century India, Dard called for a unity of the two major Muslim denominations on the basis of a theosophicalmystical framework that centred on the principles of the imamate and siyāda. He offered a comprehensive doctrine to absorb both Sunnīs and Shīīs into his way of the Muhammadiyya Wäthiqa and Khätima, "the trustworthy and final Muhammadness". Dard strengthened his comprehensive way by considering

$84 \quad$ Dard, $T / m, 88$.

85 Dard, Ilm, 88, 113-14; Khodamoradi, Sufi Reform, 145-47.

86 Ziad, "Quest of the Nightingale", 242. 
both Shīi Imams and Muhammad's companions as branches of the same Prophetic tree, no matter whether they had been "transplanted" onto it or were his real offspring. He then called upon the Muslims only to be concerned about the fruits and benefits which the tree as a whole provided for them. In his interpretation of the ahl-i bayt and the imamate which went against his Mujaddidī-Hanafì background, Dard attempted to use the widespread appreciation for descent from the Prophet (siya ada), a point of agreement between Shīīs and Sunnīs, as an axis on which both denominations could construct a common Muslim identity and revise their old controversies with a fresh perspective.

Reconsidering siya $\bar{a} d a$ and imamate, Dard affirms the right of the Imams and sādāt of Banī Fāțima to lead the Muslim community and their role as the true source of knowledge that was transmitted through the imamate after the rightly guided caliphs. He considers the allegiance of Muslims to Hasan's caliphate as the starting point of this leadership. For him the blood of the Prophet and the knowledge of 'Alī as transmitted to the founders of the Tariqa Muhammadiyya besides the centrality of the Prophet Muhammad construct the main structure and pivotal elements of this path. His declaration of the Tarīqa Muhammadiyya as a hereditary power (dawlat-i mawrüthì) expresses its authenticity, right, and capacity for the leadership of the umma via siyäda. Furthermore, Dard's affirming of a kind of infallibility of the ahl-i bayt, his stress on love for them as the criterion of faith (mahakk-i imān), and his focus on the knowledge of 'Alī embeds key elements of the Shî'i narrative of the imamate into his doctrine.

Although veneration and respect of the ahl-i bayt has always been a part not only of Sufi but also of Sunnī tradition in general, Dard's adaptation of the theory of the imamate is a step further in that respect. He considers himself an Imam, gives priority to the knowledge connected with the imamate, accentuates the figure of 'Ali as the source of such knowledge, and affirms the right of the Imams for the leadership of the Muslim umma. He certainly did not have the opportunity to round his concepts and to explain more clearly and in detail how his Țariqa Muhammadiyya Khālișa could accommodate the theory of the imamate as the highest source of knowledge. But he was courageous enough to propound such an adaptation at a time when most Sunnī reformists were engaged in anti-Shīī polemics and controversies, ${ }^{87}$ vis-à-vis an increasing

$87 \quad$ As exceptions to this, one can find some positive approaches to Shīīi belief in general by Maẓhar Jān-i Jānān and the partial, inconspicuous compromises made by Walī Allāh in affirming 'iṣma for Shīīi Imams (Walī Allāh, al-Tafhìmāt, 14). For Mazhar's approach, see Weismann, The Naqshbandiyya, 65-66; Friedmann, "Medieval Muslim Views". 
prominence of the Shīis and a decline of Sunnī power in the waning Mughal Empire. Dard's approach clearly stands in opposition to the Sunnī - and particularly Naqshbandī-Mujaddidī - revivalism of his age. This might have been one reason for his isolation, and also for the fact that he was not mentioned in the works of influential contemporaries such as Shāh Walī Allāh and Maẓhar Jān-i Jānān.

\section{Bibliography}

\section{Primary Sources}

'Abd al-'Azīz, Sh. Tuhfa ithnā 'ashariyya, ed. Ḥ. Gh. Halīm, Lucknow, Munshi Newal Kishore, n.d.

Ālemī, Kh. "Mulūk-i bahmanī wa jāygāh-i tashayyu' dar Dakan", Shīe shenāsī 10/39 (1391), 101-30.

'Andalīb, M. N. Nāla-yi 'Andalīb, 2 vols, Bhopal, Matba'at Shahjahani, 1795.

Bin Arḥama, Kh. Takhrïj hadìth: Ana madinat al-'ilm wa-'Alī bābuhāa, Riyadh, Dār al-Qabas, 2010.

Bukhārī, M. b. I. al-Jāmi' al-ṣaḥịh: Șaḥịh al-Bukhārī, 7 vols, trans. 'A. 'A. N. Ahrārī, Turbat Jam, Intisharat-i Shaykh al-Islam Ahmad-i Jam, 2007.

Dard, Kh. M. Tlm al-kitāb, Delhi, Mațba'at al-Anșārī, 1890.

Dard, Kh. M. Chahār risāla:Dard-i Dil, Bhopal, Matba'-i Shah Jahani, 1892.

Dard, Kh. M. Dìwān-i färsī, Delhi, 1892.

Dard, Kh. M. Urdū dīwān, Lahore, Majlis-i Taraqqi-i Adāb, 1962.

Ḥillī, J. b. H.. Kitāb al-maslakfì uṣūl al-dīn, ed. R. Ustadi, Mashhad, Āstānat al-Raḍawiyya al-Muqaddasa, 1994.

Ibn al-Maghāzilī, 'A. b. M. Manāqib amìr al-mu'minìn 'Alì b. Abì Ṭālib, Beirut, Dār al-Aḍwā', 2003 .

Ibn Taymiyya, A. b. 'A. Ḥ. Minhāj al-sunna al-nabawiyya fı naqd kalām al-shīa al-qadariyya, 9 vols, ed. M. R. Salim, Riyadh, Jāmi'at al-Imām Muhammad bin Sacūd al-Islāmiyya, 1986.

Kulaynī, M. b. Y. al-Ușūl min al-kāfì, 2 vols, Tehran, Dār al-Kutub al-Islāmiyya, 1990.

Mīr Ḥāmid, Ḥ. B. M. 'Abaqāt al-anwār fı̀ imāmat al-a’imma al-aṭhār, 18 vols, Qum, Mu'assasat al-Nashr al-Islāmī, n.d.

Rāzī, F. D. M. b. 'U. I'tiqādāt firaq al-muslimīn wa-l-mushrikìn, Beirut, Dār al-Kutub al-'Arabī, 1987.

Rāzì, S. D. Ḥ. al-Munqidh min al-taqlìd, 2 vols, Qum, Mu’assasat al-Nashr al-Islāmī, 1994. Sharif, M. M., trans. Șaḥ̄h Muslim: The Authentic Hadiths of Muslim, 4 vols, Beirut, Dār al-Kutub al-'Ilmiyya, 2005. 
Ṭabāțabāīî, S. 'A. 'A. "Mawqif al-shīa min hajamāt al-khuṣūm wa-khulāṣa 'an kitāb 'abaqāt al-anwār", Turāthunā 6/1 (1987), 32-61.

Walī Allāh, Sh. al-Tafhìmāt al-ilāhiyya, 2 vols, Dabhil [India], Majlis-'ilmī, 1936.

Walī Allāh, Sh. Izālat al-khafä' 'an khilāfat al-khulafä', trans. T. D. Nadwī, vol. 1, Damascus, Dār al-Qalam, 2013.

\section{Secondary Literature}

Ahmad, A. "An Eighteenth-Century Theory of the Caliphate", Studia Islamica 28 (1968), 135-44.

Ahmad, M. Saiyid Ahmad Shahid: His Life and Mission, Lucknow, Academy of Islamic Research and Publication, 1975.

Baljon, J. M. S. Religion and Thought of Shāh Wal̄ Allāh Dihlaw̄̄ 1703-1762, Leiden, Brill, 1986.

Böwering, G. "Introduction", in G. Bowering, ed., Islamic Political Thought: An Introduction, Princeton, Princeton University Press, 2015, 1-23.

Cole, J. R. I. Roots of North Indian Shi' ism in Iran and Iraq: Religion and State in Awadh, 1722-1856, Berkeley, University of California Press, 1989.

Dahnhardt, T. Change and Continuity in Indian Sufism: A Naqshbandi-Mujaddidi Branch in the Hindu Environment, New Delhi, D. K. Printworld, 2002.

Dallal, A. "The Origins and Objectives of Islamic Revivalist Thought, 1750-1850", Journal of the American Oriental Society 113 (1993), 343-49.

Friedmann, Y. "Medieval Muslim Views of Indian Religions", Journal of the American Oriental Society 95/2 (1975), 214-21.

Gaborieau, M. Le Mahdi incompris: Sayyid Ahmad Barelwî (1786-1831) et le millénarisme en Inde, Paris, CNRS, 2010.

Gleave, R. Scripturalist Islam: The History and Doctrines of the Akhbārì Shī̄ School, Leiden, Brill, 2007.

Hermansen, M. K., trans. The Conclusive Argument from God: Shāh Walī Allāh of Delhi's Hujjat Allāh al-Bāligha, Leiden, Brill, 1995.

Hyder, S. A. Reliving Karbala: Martyrdom in South Asian Memory, New York, Oxford University Press, 2006.

Irvine, W. Later Mughals, 2 vols, New Delhi, Rawat Publications, 1995.

Jacfariyān, R. "Mukātibat-i Mīr Yūsif 'Alī Astarābādī bā Qāḍī Nūr Allāh Shūshtarī", Āyeneye pajūhesh 20/1 (1388/2009), 2-15.

Khodamoradi, S. "Ṭarīqah Muhammadiyyah as Țarīqah Jāmi'ah: Khwajah Mir Dard's Experience Beyond Jamāl and Jalāl', Islamic Studies 51/4 (2012), 367-402.

Khodamoradi, S. Sufi Reform in Eighteenth Century India: Khwaja Mir Dard of Delhi (1721-1785), Berlin, EB-Verlag, 2019.

Madelung, W. The Succession to Muhammad: A Study of the Early Caliphate, Cambridge, Cambridge University Press, 1997. 
Mavani, H. Religious Authority and Political Thought in Twelver Shi ism from Ali to Post-Khomeini, Abingdon, Routledge, 2013.

Nasr, V. The Shi'a Revival: How Conflicts within Islam will Shape the Future, New York, Norton, 2006.

Newman, A. J. "The Nature of Akhbārī/Ușūlī Dispute in late Șafawid Iran, Part 1: 'Abdallāh al-Samāhijī's Munyal al-Mumārisīn", Bulletin of the School of Oriental and African Studies 55/1 (1992), 22-51.

Newman, A. J. "The Nature of Akhbārī/Ușūlī Dispute in late Șafawid Iran, Part 2: The Conflict Reassessed", Bulletin of the School of Oriental and African Studies 55/2 (1992), 250-61.

Pinault, D. The Shicites: Ritual and Popular Piety in a Muslim Community, London, Palgrave Macmillan, 1992.

Rezavi, S. A. N. "The State, Shi'as and Shi'ism in Medieval India”, Studies in People's History 4/1 (2017), 32-45.

Rieck, A. T. The Shias of Pakistan: An Assertive and Beleaguered Minority, Oxford, Oxford University Press, 2015.

Rizvi, S. "Faith Deployed for a New Shici Polity in India: The Theology of Sayyid Dildar 'Ali Nasirabadi", in J. Jones and A. U. Qasmi, eds, The Shi'a in Modern South Asia: Religion, History and Politics, Delhi, Cambridge University Press, 2015, 12-35.

Rizvi, S. A. A. Shah Wali-Allah and His Times: A Study of Eighteenth-Century Islām, Politics and Society in India, Canberra, Ma'rifat Publishing House, 1980.

Rizvi, S. A. A. Shah 'Abd al-'Aziz: Puritanism, Sectarianism, Polemics and Jihad, Canberra, Ma'rifat Publishing House, 1982.

Rizvi, S. A. A. "Bārha Sayyids", in P. Bearman et al., eds, Encyclopaedia of Islam, Second Edition (online). Accessed 18 February 2020. http://dx.doi.org/10.1163/1573 -3912_islam_SIM_8403.

Saghaeearaj, N. “Muhammad Nāșir ‘Andalīb’s Sufi Path Based on His Lament of the Nightingale: Revisiting Mystical Islam in Eighteenth-Century India”, PhD diss., University of Erfurt, 2018.

Schimmel, A. Pain and Grace: A Study of Two Mystical Writers of Eighteenth-Century Muslim India, Leiden, Brill, 1976.

Storey, C. A. Persian Literature: A Bio-bibliographical Survey, vol. 1, London, Royal Asiatic Society, 2002.

Umar, M. "Mirza Mazhar Jan-i Janan: A Religious Reformer of the Eighteenth Century", Studies in Islam 6 (1969), 118-54.

Umar, M. Islam in Northern India during the Eighteenth Century, New Delhi, Munshiram Manoharlal, 1993.

Voll, J. O. Islam: Continuity and Change in the Modern World, Syracuse, Syracuse University Press, 1994. 
Weismann, I. The Naqshbandiyya: Orthodoxy and Activism in a Worldwide Sufi Tradition, London, Routledge, 2007.

Wynbrandt, J. A Brief History of Saudi Arabia, New York, Checkmark Books, 2004.

Ziad, H. "I Transcend Myself like a Melody, Khwājah Mīr Dard and Music in Eighteenth-Century Delhi", The Muslim World 97 (2007), 548-70.

Ziad, H. "Quest of the Nightingale: The Religious Thought of Khvājah Mīr Dard (17201785)", PhD diss., Yale University, 2008. 